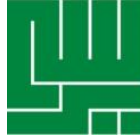

KATA KUNCI

KEYWORDS

ABSTRAK

\section{Perbedaan Tingkat Kecemasan Pada Dokter Gigi Muda Dan Perawat Gigi Muda Saat Menghadapi Pasien}

\section{The Difference Level Of Anxiety In Junior Dentists And Dental Nurses In Treating The Patients}

\author{
Rini Julistia ${ }^{1}$, Kartika Sari ${ }^{2}$, Arum Sulistyani $^{3}$ \\ Program Studi Psikologi Fakultas Kedokteran Universitas Syiah Kuala \\ Email: rinijulistia90@gmail.com
}

\section{Kecemasan, Dokter Gigi Muda, Perawat Gigi Muda}

Anxiety, Junior dentist, Junior dental nurse.

Kecemasan adalah suatu keadaan emosi yang tidak menyenangkan yang dialami individu ketika berfikir mengenai sesuatu yang tidak menyenangkan akan terjadi, sehingga menimbulkan perasaan takut, kehati-hatian dan kewaspadaan. Salah satu faktor yang membedakan tingkat kecemasan yaitu lingkungan belajar.Perbedaan lingkungan belajar ini ditemukan pada dokter gigi muda dan perawat gigi muda.Lingkungan belajar dokter gigi muda memiliki tuntutan tinggi dan penuh dengan tekanan jiwa, seperti, kurikulum materi yang menuntut dokter gigi muda untuk memiliki bermacam-macam kemampuan dan keahlian, termasuk kemahiran dalam pengetahuan teori, kompetensi klinik, dan keterampilan. Sementara itu, pada lingkungan belajar perawat gigi muda terdapat beban kerja yang lebih bersifat fisik seperti melakukan perawatan ringan, merapikan kursi dental, dan mensterilkan alat-alat. Penelitian ini bertujuan untuk mengetahui perbedaan tingkat kecemasan pada dokter gigi muda dan perawat gigi muda saat menghadapi pasien.Penelitian ini menggunakan metode kuantitatif dengan teknik proportional sampling. Jumlah keseluruhan subjek penelitian adalah 200 orang, yang terdiri dari 100 orang dokter gigi muda dan 100 orang perawat gigi muda. Data dikumpulkan melalui skala kecemasan yang terdiri dari 28 pernyataan.Analisis data menggunakan teknik Mann-Whitney dengan hasil $Z$ yang di peroleh yaitu sebesar $-4,242(p=0,000$ $<0,05)$. Dengan demikian hasil penelitian menunjukkan bahwa terdapat perbedaan tingkat kecemasan pada dokter gigi muda dan perawat gigi muda saat menghadapi pasien.

ABSTRACT Anxiety is an unpleasant emotional state that experienced by individuals when they are thinking about something unpleasant will be occurred, so that evokes the feeling of fearness, caution and vigilance. One of the factors that differentiated the level of anxiety is the learning environment. The differences about the learning 


\begin{abstract}
environment were found in junior dentist and junior dental nurse. The learning environment of junior dentists indicated higher demands and stressful. The curriculum required junior dentist to have variety of abilities, including proficiency in theoritical knowledge, clinical competence and skills. Meanwhile, the junior dental nurses emphasized on a workload in physical activities such as doing simple treatment, tidying dental chairs and sterilizing the equipments. This study was aimed to determine the difference level of anxiety in junior dentists and dental nurses in treating the patients. This study used quantitative method with proportional sampling technique. The total participants in the study were 200 people. It consist of 100 junior dentists and 100 junior dental nurses. The data was collected through the Scale of Anxiety which consists of 28 statements. The analysis of data using the Mann Whitney technique with results obtained $Z$ which is equal to -4.242 $(p=0.000<0,05)$. In conclusion, the results of the study indicate that there was difference in the level of anxiety in junior dentists and junior dental nurses in treating the patients.
\end{abstract}

\section{PENDAHULUAN}

Kecemasan adalah suatu keadaan emosi yang tidak menyenangkan yang dialami individu ketika berfikir mengenai sesuatu yang tidak menyenangkan akan terjadi, sehingga menimbulkan perasaan takut, kehatihatian dan kewaspadaan. Kecemasan dapat muncul pada situasi seperti berbicara di depan umum, tekanan pekerjaan yang tinggi, menghadapi ujian, dan pada situasi-situasi tertentu juga dapat memicu munculnya kecemasan bahkan rasa takut. Sigmund Freud menyebutkan bahwa timbulnya rasa cemas dapat diketahui dari perilaku yang ditimbulkan oleh individu tersebut. Kecemasan sangat berhubungan erat dengan rasa takut, sehingga dapat terjadi secara tidak sadar (Dennis \& Christine, 2004).

Kecemasan adalah respon individu terhadap suatu keadaan yang tidak menyenangkan yang dialami oleh setiap makhluk hidup dalam kehidupan sehari-hari.Kecemasan merupakan pengalaman subjektif dari individu dan tidak dapat diobservasi secara langsung serta merupakan suatu keadaan emosi tanpa objek spesifik.Kecemasan pada individu dapat memberikan motivasi untuk mencapai sesuatu dan merupakan sumber penting dalam usaha memelihara keseimbangan hidup.Kecemasan terjadi akibat dari ancaman terhadap harga diri yang sangat mendasar bagi keberadaan individu (Suliswati, 2005).

Menurut Daradjat (dalam Sijangga, 2010) kecemasan merupakan manifestasi dari berbagai proses emosi yang terjadi saat individu mengalami tekanan perasaan dan pertentangan batin. Kecemasan tersebut memiliki segi yang disadari, seperti rasa takut, terkejut, tidak berdaya, rasa bersalah, maupun terancam. Kecemasan juga memiliki segi yang di luar kesadaran dan tidak jelas, seperti takut tanpa mengetahui sebabnya dan tidak bisa menghindari perasaan yang tidak menyenangkan. Kecemasan merupakan ketakutan yang tidak menyenangkan, atau suatu pertanda sesuatu yang buruk akan terjadi (Harber dan Runyon dalam Puspitasari, Abidin, Sawitri, 2010).

Kecemasan biasanya timbul karena adanya respon terhadap kondisi stres atau adanya konflik. Hal ini 
biasanya terjadi ketika individu mengalami perubahan situasi dalam hidupnya dan dituntut untuk mampu beradaptasi dengan lingkungan barunya (Solomon dalam Widosari, 2011). Hal ini sejalan dengan penelitian yang dilakukan oleh Suyamto, Prabandari dan Marchira (2009), tentang kecemasan pada mahasiswi keperawatan ketika menjelang ujian akhir. Hasil penelitian menjelaskan bahwa kecemasan yang dialami mahasiswi keperawatan memengaruhi perilaku adaptif (kemampuan individu yang berkaitan dengan fungsi kemandirianuntuk mencapai keberhasilan). Kecemasan dapat dikurangi dengan promosi kesehatan berupa relaksasi kecemasan dan stres sehingga dapat membantu mahasiswi untuk mengoptimalkan kegiatannya.

Harber dan Runyon (dalam Puspitasari, Abidin, Sawitri, 2010) mengemukakan empat dimensi kecemasan yaitu:

a. Dimensi kognitif yaitu perasaan tidak menyenangkan yang muncul dalam pikiran individu sehingga mengalami rasa cemas dan khawatir. Kekhawatiran ini dapat terbentuk mulai dari tingkat khawatir yang ringan, panik, cemas, merasa akan terjadi malapetaka, kiamat, dan kematian, saat individu mengalami kondisi ini ia tidak dapat berkonsentrasi, mengambil keputusan, dan mengalami kesulitan untuk tidur.

b. Dimensi motorik yaitu perasaan tidak menyenangkan yang muncul dalam bentuk tingkah laku seperti meremas jari, menggeliat, menggigit bibir, menjentikkan kuku, dan gugup.

c. Dimensi somatis yaitu perasaan tidak menyenangkan yang muncul dalam reaksi fisik biologis seperti mulut terasa kering, kesulitan bernafas, berdebar, tangan dan kaki dingin, pusing banyak keringat, tekanan darah naik, otot leher dan bahu terasa tegang, serta sulit mencerna makanan.

d. Dimensi afektif yaitu perasaan tidak menyenangkan yang muncul dalam bentuk emosi, perasaan tegang karena luapan emosi yang berlebihan seperti dihadapkan pada suatu teror. Luapan emosi ini biasanya berupa kegelisahan atau kekhawatiran bahwa ia dekat dengan bahaya padahal sebenarnya tidak terjadi apa-apa.

Kecemasan juga dialami oleh dokter gigi muda dan perawat gigi muda ketika menghadapi pasien. Dokter gigi muda adalah salah satu tenaga kesehatan utama dalam memberikan pelayanan kesehatan kepada masyarakat yang mempunyai peran penting, hal ini terkait dengan mutu pelayanan, dan penyelenggaraan upaya kesehatan yang memiliki etik, moral, keadilan dan kewenangan yang secara terus menerus harus ditingkatkan dan salah satu unsur utama dalam sistem pelayanan kesehatan (Konsil Kedokteran Indonesia, 2006).Perawat gigi muda adalah salah satu profesi kesehatan yang memberikan pelayanan kesehatan gigi di instansi pelayanan kesehatan seperti Rumah Sakit, Puskesmas, dan sarana kesehatan lainnya. Perawat gigi muda termasuk kategori tenaga kesehatan karena memenuhi kriteria seperti mengabdikan dirinya dalam bidang kesehatan gigi dan mulut, memiliki pengetahuan dan keterampilan melalui pendidikan keperawatan gigi, memiliki kewenangan tertentu dalam melakukan asuhan kesehatan gigi dan mulut (Departemen Kesehatan Republik Indonesia, 2008).

Berdasarkan hasil penelitian yang dilakukan oleh Widosari (2010), diketahui bahwa terdapat beberapa faktor kecemasan yang dialami oleh dokter gigi muda, antara lain, tuntutan untuk lebih aktif dalam proses belajar mengajar yaitu masing-masing kelompok mahasiswa 
memiliki tanggung jawab dan tugas, dimana mahasiswa preklinik (mahasiswa yang sedang menjalani pendidikan) selain menjalani masa perkuliahan juga menghadapi ujian, melengkapi syarat kelulusan seperti karya tulis ilmiah. Namun, dokter gigi muda selain menghadapi ujian dan melengkapi syarat kelulusan untuk tiap bagian (stase) juga harus menghadapi pasien secara langsung dan memiliki tanggungjawab terhadap keselamatan pasien, dengan demikian, dokter gigi muda dituntut untuk lebih aktif baik dalam belajar maupun dalam mengambil tindakan. Kedua, lebih kompetitif yaitu suasana belajar dokter gigi muda di rumah sakit yang berhadapan langsung dengan pasien lebih kompetitif dibanding suasana belajar mahasiswa preklinik di Universitas.Hal ini dikarenakan ketika praktik dilapangan individu tersebut harus berhadapan langsung dengan staf pengajar di rumah sakit, dan adanya persaingan antar dokter gigi muda, dokter gigi muda tidak ingin ketinggalan dari teman-teman lainnya dalam keterampilan menangani pasien.

Faktor kecemasan lainnya adalah jadwal yang padat, dokter gigi muda menghabiskan waktu di rumah sakit lebih banyak daripada mahasiswa preklinik menghabiskan waktu di ruang kuliah.Setiap dokter gigi muda memiliki jadwal jaga masing-masing dan berbagai aktivitas yang menguras tenaga.Waktu istirahat yang relatif lebih sedikit menyebabkan dokter gigi muda cenderung lebih lelah daripada mahasiswa preklinik.Keempat, materi kuliah yang dipelajari sangat luas dan lebih aplikatif.Dokter gigi muda dituntut untuk terampil dalam mengaplikasikan seluruh materi kuliah yang telah dipelajari saat kuliah preklinik. Keadaan ini dapat menciptakan stresor yang memicu timbulnya kecemasan atau depresi (Prawirohusodo dalam Widosari, 2011).

Perawat gigi muda merupakan tenaga kesehatan yang memberikan pelayanan terhadap individu yang membutuhkan dengan menggunakan berbagai alat bantu kesehatan yang lengkap (Hartoyo, 2008). Berdasarkan Keputusan Menteri Kesehatan nomor 94 tahun 2001 tugas pokok perawat adalah memberi pelayanan keperawatan dalam upaya peningkatan kesehatan, pencegahan, penyembuhan penyakit, pemulihan kesehatan, serta membina masyarakat agar lebih mandiri dalam mendapatkan perawatan kesehatan (Proborani, Hartati \& Sawitri, 2010).

Pelayanan kesehatan yang diberikan oleh perawat gigi untuk masyarakat menuntut keterampilan dalam menggunakan alat bantu kesehatan. Hal ini merupakan bagian terpenting dalam menjalankan sebagian besar aktivitas di rumah sakit. Pemakaian alat yang serba lengkap dapat menimbulkan kecemasan pada perawat gigi dalam memberikan pelayanan kepada pasien, sehingga menimbulkan rasa takut gagal dalam memberikan tindakan medis (Hartoyo 2008).

Pada dasarnya penyebab timbulnya kecemasan pada dokter gigi dan perawat gigi muda dikarenakan banyaknya tuntutan dari masyarakat, sehingga memengaruhi persepsi masyarakat bahwa kedua profesi tersebut mampu memberikan pelayanan dengan baik.Sementara fakta di lapangan menunjukkan bahwa faktor munculnya kecemasan disebabkan oleh kurangnya pengetahuan, rasa percaya diri dan adanya tekanan dari dokter instruktur, sehingga menimbulkan kekhawatiran dalam melakukan penanganan (Prawirohusodo dalam Widosari, 2011).

Hal tersebut juga sesuai dengan survei yang dilakukan dengan cara mewawancarai mahasiswa/mahasiswi 
serta staff pengajar di Rumah Sakit Gigi dan Mulut dan Laboratorium Politeknik Kesehatan Aceh oleh peneliti, diketahui bahwa kedua profesi ini memiliki persamaan yaitu sama-sama menangani masalah kesehatan gigi dan mulut. Selain adanya persamaan pada kedua profesi ini terdapat juga beberapa perbedaan antara dokter gigi muda dan perawat gigi muda, diantaranya adalah: 1) Lulusan dokter gigi muda di Kota Banda Aceh masih sedikit, sedangkan lulusan perawat gigi muda di Kota Banda Aceh sudah cukup banyak, 2) Rumah Sakit Gigi dan Mulut tempat para dokter gigi muda mengambil profesi dokter yang baru didirikan selama enam tahun sedangkan Poliklinik Kesehatan Aceh merupakan tempat perawat gigi muda melakukan praktik yang telah berdiri selama 13 tahun, 3) Dokter gigi muda harus lebih terampil dibandingkan dengan perawat gigi muda, 4) Dokter gigi muda dituntut untuk menangani pasien secara langsung, sementara perawat gigi muda hanya sebagai asisten dokter, 5) Dokter gigi muda ketika mengambil profesi, menangani pasien dengan berbagai macam kasus dan intervensi, sedangkan perawat gigi muda hanya menangani halhal tertentu saja, seperti penambalan, pembersihan karang gigi dan pencabutan gigi, 6) Masa studi dokter gigi muda sebelas semester, sedangkan masa studi perawat gigi muda hanya enam semester, 7) Dokter gigi muda melakukan praktik dan menghadapi pasien setelah mendapatkan gelar sarjana kedokteran gigi, sedangkan perawat gigi muda melakukan praktik atau menangani pasien sejalan dengan belajar materi atau teori. Dengan adanya sejumlah perbedaan ini peneliti ingin melihat apakah ada perbedaan tingkat kecemasan pada dokter gigi muda dan perawat gigi muda saat menghadapi pasien.

\section{METODOLOGI PENELITIAN}

Penelitian ini menggunakan metode kuantitatif dengan teknik pengambilan sampel proportional sampling.Populasi dalam penelitian ini adalah mahasiswa/mahasiswi kedokteran gigi Universitas Syiah Kuala dan Politeknik Kesehatan Aceh jurusan keperawatan gigi. Jumlah subjek 200 orang, yang terdiri dari 100 orang dokter gigi muda dan 100 orang perawat gigi muda dengan kriteria sebagai berikut: (a) Individu yang sedang menjalani praktik klinik (koas) di Rumah Sakit Gigi dan Mulut dan Laboratorium Politeknik Kesehatan Aceh.

Data dalam penelitian ini dikumpulkan melalui skala kecemasan yang disusun oleh peneliti berdasarkan dimensi kecemasan yang dikemukakan oleh Harber dan Runyon (dalam Puspitasari, Abidin, Sawitri, 2010) yaitu dimensi kognitif, motorik, somatis, afektif. Skala kecemasan berisi 28 pernyataan dengan empat alternatif pilihan jawaban yaitu (a) Sangat Sering (SS), (b) Sering (S), (c) Kadang-Kadang (K), (d) Tidak Pernah (TP). Pemberian skor dari jawaban yang dipilih bergerak dari angka 1 sampai 4.

Analisis data yang digunakan untuk menguji hipotesis dalam penelitian ini adalah analisis statistik uji MannWhitney dengan menggunakan software SPSS versi 17.0 for windows.

\section{ANALISIS DAN HASIL Deskripsi Data}

Untuk mendapatkan gambaran umum mengenai data penelitian secara singkat dapat dilihat pada tabel 1, dimana terdapat perbedaan antara data hipotetik (yang mungkin terjadi) dan 
data empirik (berdasarkan kenyataan di lapangan).

Tabel 1. Deskripsi Data Penelitian

\begin{tabular}{lllll}
\hline Jenis & \multicolumn{4}{c}{ Variabel: Kecemasan } \\
\cline { 2 - 4 } Data & Xmaks & Xmin & Mean & SD \\
\hline Data & 112 & 28 & 70 & 14 \\
Hipotetik & & & & \\
Data & 80 & 28 & 55,68 & 10,246 \\
Empirik & & & \\
\hline & Deskripsi hasil data penelitian \\
tersebut dapat dijadikan batasan dalam \\
pengkategorian sampel penelitian yang \\
terdiri dari dua kategori sampel \\
penelitian, yaitu tinggi dan rendah untuk \\
skala kecemasan. Pada pembagian \\
kategori sampel penelitian digunakan \\
batas kisaran skor atau fluktuasi skor \\
mean (Azwar, 2010). Untuk pembagian \\
dua kategorisasi ini dapat dilakukan \\
dengan menggunakan batasan kisaran \\
skor mean atau fluktuasi skor mean \\
dengan cara mendapatkan standar error \\
terlebih dahulu yaitu : \\
Se = Sx $\sqrt{(((1-r x x '))}$ \\
$=10,246 \sqrt{ }((1-0,839))$ \\
$=10,246 \sqrt{ }(0,161)$ \\
$=10,246 \times 0,401$ \\
$=4,108$
\end{tabular}

Setelah mendapatkan standar error, selanjutnya peneliti melihat nilai untuk fluktuasi skor mean dengan cara:

Tabel 2. Kategorisasi Tingkat kecemasan Pada Dokter Gigi Muda dan Perawat gigi Muda

\begin{tabular}{llllccc}
\hline \multirow{2}{*}{ Kategori } & \multirow{2}{*}{$\begin{array}{l}\text { Rumus } \\
\text { Norma }\end{array}$} & Skor & & \multicolumn{2}{c}{ Jumlah } & \multicolumn{2}{c}{ Persentase } \\
\cline { 3 - 7 } & & $\begin{array}{c}\text { Dokter Gigi } \\
\text { Muda }\end{array}$ & $\begin{array}{c}\text { Perawat } \\
\text { Gigi Muda }\end{array}$ & $\begin{array}{c}\text { Dokter } \\
\text { Gigi Muda }\end{array}$ & $\begin{array}{c}\text { Perawat } \\
\text { Gigi Muda }\end{array}$ \\
\hline Tinggi & $\begin{array}{l}\mathrm{X} \geq \mathrm{M}+ \\
7\end{array}$ & $\begin{array}{l}\mathrm{X} \geq \\
55,68\end{array}$ & 43 & 15 & $43 \%$ & $15 \%$ \\
Rendah & $\mathrm{X}<\mathrm{M}-$ & $\begin{array}{l}\mathrm{X}< \\
5\end{array}$ & 19 & 32 & $19 \%$ & $32 \%$ \\
\hline
\end{tabular}

Hasil kategorisasi kecemasan dapat dilihat pada tabel 3 yang menunjukkan bahwa kecemasan pada dokter gigi muda sebesar 19 persen terdapat pada kategori rendah, dan 43
$\mathrm{X} \pm \mathrm{Z} \alpha / 2$ ( se)

$\mathrm{X} \pm 1,65(4,108)$

$\pm 6,77$ atau dibulatkan menjadi \pm 7

Setelah mendapatkan nilai batasan atau fluktuasi mean, maka jumlah mean data empirik ditambahkan dengan fluktuasi skor mean untuk melihat kategorisasi tinggi, sedangkan untuk melihat kategorisasi sedang skor mean dikurangi dengan batasan fluktuasi skor mean. Seperti, skor mean 55,68 maka batasan skor untuk kategori tinggi dimulai dari skor 55,68+7 =62,68 sedangkan batas skor untuk kategori rendah di mulai pada skor 55,68-7= 48,68 . Individu yang memperoleh skor 63,00 pada skala dapat dikategorikan memiliki kecemasan tinggi sedangkan individu yang memperoleh skor 47,00 dapat dikategorikan memiliki kecemasan rendah. Individu yang skornya berada di antara 48,68 - 62,68 tidak perlu diklasifikasikan karena tujuan semula hanya untuk memisahkan subjek ke dalam dua kategori saja.

Hasil kategorisasi tingkat kecemasan pada dokter gigi muda dan perawat gigi muda dapat dilihat pada tabel berikut: 
dan 15 persen pada kategori tinggi, sedangkan sebanyak 53 persen berada pada batas kisaran skor atau fluktuasi skor mean.

\section{Uji Hipotesis}

Sebelum dilakukan uji hipotesis, terlebih dahulu diuji normalitas data yang merupakan syarat harus dipenuhi sebelum melakukan uji hipotesis. Hasil uji normalitas yang dilakukan pada 200 responden, Skala kecemasan pada dokter gigi muda memiliki sebaran normal $(\mathrm{K}$ $S-Z=0,844$ dengan $p>0,05)$, sedangkan perawat gigi muda juga memiliki sebaran normal $(\mathrm{K}-\mathrm{S}-\mathrm{Z}=1,056$ dengan p>0,05), maka dapat disimpulkan bahwa data penelitian memiliki sebaran normal, kemudian berdasarkan uji homogenitas yang dilakukan maka didapatkan hasil dengan nilai signifikansi sebesar 0,006 , karena signifikansi lebih kecil dari 0,05 maka dapat disimpulkan bahwa data penelitian ini mempunyai varians yang berbeda atau dengan kata lain varians datanya bersifat tidak homogen. Setelah mendapatkan hasil dari uji normalitas (data normal)dan homogenitas (data tidak homogen), maka peneliti menggunakan analisis korelasi non parametrik yaitu Mann-Whitney untuk mengetahui apakah ada perbedaan antara dua kelompok sampel.

Hasil dari analisis uji MannWhitney menunjukkan bahwa nilai mean dokter gigi muda $(117,85)$ lebih besar daripada nilai mean perawat gigi muda $(83,15)$, dan nilai uji Mann-Whitney, dapat dilihat pada statistik uji $\mathrm{Z}$ yang kecil yaitu $-4,242$ dan nilai sig.2-tailed adalah $0,000<0,05$. Hal ini menunjukkan bahwa ada perbedaan antara tingkat kecemasan pada dokter gigi muda dengan perawat gigi muda. Berdasarkan hasil tersebut maka dapat dikatakan bahwa hipotesis penelitian yang berbunyi "Ada perbedaan tingkat kecemasan pada dokter gigi muda dan perawat gigi muda saat menghadapi pasien", dapat diterima.

Hasil analisis statistik pada setiap dimensi kecemasan diperoleh hasil bahwa dimensi kognitif memiliki persentase yang paling tinggi pada dokter gigi muda dan perawat gigi muda jika dibandingkan dengan dimensi lain. Berdasarkan hasil kategorisasi pada dimensi kognitif menunjukkan bahwa sebesar 21 persen dokter gigi muda mengalami kecemasan tinggi dan sebesar 6 persen mengalami kecemasan rendah, sedangkan 73 persen tidak tergolong dalam kategori tinggi ataupun rendah karena berada pada batas kisaran atau fluktuasi skor mean. Perawat gigi muda mengalami kecemasan tinggi yaitu sebesar 10 persen dan sebesar 8 persen mengalami kecemasan rendah, sedangkan 82 persen tidak tergolong dalam kategori tinggi ataupun rendah karena berada pada batas kisaran atau fluktuasi skor mean.

\section{DISKUSI}

Berdasarkan hasil penelitian yang telah dilakukan pada dokter gigi muda dan perawat gigi muda yang sedang menjalani praktik klinik di Rumah Sakit Gigi Mulut dan Laboratorium Poltekes Aceh menunjukkan bahwa ada perbedaan tingkat kecemasan yang signifikan pada dokter gigi muda dan perawat gigi muda, hal ini ditunjukkan dengan nilai $\mathrm{Z}$ yang diperoleh yaitu sebesar -4,242 dengan harga $P$ $(0,000<0,05)$. Maka dapat dikatakan bahwa hipotesis penelitian ini diterima. Kecemasan merupakan bagian terbesar di dalam kehidupan manusia, sehingga kecemasan dapat menghambat kegiatan yang akan dilakukan oleh dokter gigi muda dan perawat gigi muda dalam memberikan pelayanan dan perawatan kepada pasien. Kecemasan adalah suatu respon psikologis dan tingkah laku 
terhadap stres yang terkadang merupakan bagian penting dari pengalaman manusia.Hal ini disebabkan oleh pengalaman yang menegangkan serta adanya berbagai masalah yang tidak terselesaikan. Kecemasan yang dialami oleh individu akan menjadikan pengganggu yang akan menghambat kegiatan sehingga individu tidak mampu melakukan apa yang inginkannya dengan mudah (Hawari dalam Wiyono \& Widodo, 2010).

Berdasarkan hasil penelitian yang dilakukan oleh Kaplan dan Saddock (dalam Widosari, 2010) tentang perbedaan kecemasan pada mahasiswa pre klinik dan ko-asisten disebabkan oleh dua faktor, yaitu stressor psikososial dan perubahan lingkungan.Stressor psikososial terjadi karena adanya perubahan dalam kehidupan individu sehingga individu harus beradaptasi kembali dengan kehidupannya. Perubahan lingkungan memengaruhi hasil belajar individu, seperti adanya kebingungan dan distorsi persepsi, dimana distorsi tersebut dapat mengganggu belajar, menurunkan kemampuan dalam memusatkan perhatian, daya ingat, dan menghubungkan satu hal dengan hal yang lain.

Perbedaan tingkat kecemasan pada dokter gigi muda dan perawat gigi muda terlihat dari kategorisasi kecemasan dokter gigi muda, dimana dokter gigi muda memiliki tingkat kecemasan yang tergolong tinggi sebesar 43 persen, sedangkan perawat gigi muda hanya sebesar 15 persen. Perbedaan tersebut disebabkan oleh adanya perbedaan keadaan atau kondisi yang dialami kedua kelompok subjek (dokter gigi muda dan perawat gigi muda) seperti, tuntutan lingkungan belajar yang dialami oleh dokter gigi muda lebih tinggi dan penuh dengan tekanan (stressful) seperti, kurikulum materi yang menuntut dokter gigi muda untuk memiliki bermacam-macam kemampuan dan keahlian, termasuk kemahiran dalam pengetahuan teori, kompetensi klinik, dan keterampilan dalam berhubungan dengan orang-orang (interpersonal skill) (Polimpung, 2012). Penelitian yang dilakukan oleh Alzahem dkk (2010) menyatakan bahwa kecemasan pada dokter gigi muda dikarenakan adanya ujian dalam setiap bidang atau bagian, kebutuhan syarat klinik, dan dokter jaga pada klinik (dental supervisor).

Menurut Melamed dan Williansom (dalam Karaogli \&Seker , 2006) menyatakan bahwa banyak dokter gigi yang mengaku dirinya cemas saat menghadapi pasien. Kecemasan ini disebabkan karena frustrasi yang timbul akibat penolakan dari pasien, dan tidak mampu menciptakan hubungan yang baik antara dokter dan pasien ketika memberikan perawatan. Faktor lain yang memengaruhi tingkat kecemasan pada dokter gigi yaitu terpaksa menjadi dokter dengan tujuan untuk mendapatkan uang lebih banyak, dan tekanan dari luar seperti tuntutan orang tua (Melamed dan Williansom dalam Karaogli \& Seker, 2006).

Menurut Lestarianita dan Fakhrurrozi (2007) setiap pekerjaan dapat menimbulkan stres dan cemas pada para pekerjanya.Salah satunya adalah profesi seorang perawat.Seorang perawat seringkali dihadapkan pada permasalahan dan resiko yang berhubungan dengan pasien yang sedang dirawatnya, dan keadaan inilah yang dapat memunculkan kecemasan. Perawat merupakan individu yang memiliki pekerjaan yang menuntut tingkat kesabaran yang tinggi dan seringkali perawat diwajibkan untuk dapat mengambil keputusan dengan segera ketika ada pasien yang datang. Kemudian bila dikaitkan dengan tugas perawat pada saat menghadapi pasien 
yaitu: a) Melaksanakan instruksi dokter yaitu mengobservasi gejala dan respon pasien yang berhubungan dengan penyakit dan penyebabnya, b) memantau pasien, menyusun dan memperbaiki rencana keperawatan secara terusmenerus berdasarkan pada kondisi dan kemampuan pasien, c) mencatat dan melaporkan keadaan pasien, d) melaksanakan prosedur dan teknik keperawatan, e) memberikan pengarahan dan penyuluhan untuk meningkatkan kesehatan fisik dan mental. Hal ini disebabkan perawat harus bertindak dengan cepat saat menghadapi pasien, dikarenakan perawat memiliki tanggung jawab ketika terjadi sesuatu dengan pasien yang mereka tangani (Phaneuf dalam Lestarianita dan Fakhrurrozi, 2007).

Selanjutnya terdapat beberapa faktor lainnya yang dapat memengaruhi terjadinya perbedaan kecemasan pada dokter gigi muda dan perawat gigi muda.Perawat gigi muda lebih tenang dalam menghadapi pasien dibandingkan dengan dokter gigi muda.Hal ini juga sejalan dengan pendapat Nursalam (2002) yang mengatakan bahwa beban kerja perawat gigi lebih bersifat fisik seperti melakukan perawatan ringan (seperti penambalan pada gigi, dan pembersihan karang gigi), merapikan kursi dental unit, mensterilkan alat-alat gigi.Pelayanan kesehatan yang dilakukan secara rutin dan sistematik serta peran dan tuntutan inilah yang sering memunculkan kondisi yang dapat memicu terjadinya kecemasan pada perawat gigi muda.

Berdasarkan analisis statistik pada setiap dimensi kecemasan diperoleh hasil bahwa dimensi kognitif merupakan dimensi yang memiliki tingkat kecemasan paling tinggi pada dokter gigi muda dan perawat gigi muda. Dimensi kognitif adalah perasaan yang tidak menyenangkan yang muncul dalam pikiran sehingga mengalami rasa khawatir seperti merasa akan terjadi malapetaka, sulit berkonsentrasi dan sulit mengambil keputusan. Dokter gigi dan perawat gigi muda yang dapat mengendalikan dirinya tidak akan membiarkan kecemasan yang dialaminya memengaruhi dimensi-dimensi lain dalam kehidupan seperti dimensi motorik, ataupun dimensi somatis. Hal ini dikarenakan individu tersebut dapat mengontrol efek dari kecemasan yang dialaminya sehingga tidak merusak bagian lain dari kehidupannya.

Hal tersebut sesuai dengan pendapat Barlow (dalam Polimpung, 2012) yang menyatakan bahwa karakteristik kognitif utama yang dimiliki oleh individu adalah kemampuan yang kuat untuk mengontrol diri sehingga cenderung mengevaluasi dan menilai diri sendiri dengan standar yang telah ditetapkan secara subjektif dan istimewa.Menurut Barlow (dalam Polimpung, 2012) kemampuan untuk mengendalikan diri, merupakan salah satu faktor yang dapat menurunkan tingkat kecemasan sehingga individu tersebut dapat memberikan perawatan yang optimal saat menangani pasien.

Karakteristik lain yang memengaruhi kecemasan pada profesi ini adalah tidak adanya rasa optimisme atau merasa khawatir akan terjadi malapetaka. Perasaan ini merupakan salah satu dari dimensi kognitif yang dikemukakan oleh Prasetyo dan Wurjaningrum (2008) dimana individu yang tidak memiliki rasa optimis tidak dapat mengendalikan masalah yang dihadapinya dan akan mudah terpengaruh dengan masalah tersebut. Hal tersebut sesuai dengan pendapat Bernstein (dalam Prasetyo dan Wurjaningrum, 2008) yang mengemukakan bahwa tidak adanya optimisme akan membuat individu melihat kehidupan sebagai suatu hal 
yang mengancam dan tidak menyenangkan sehingga akan berperan dalam meningkatkan kecemasan. Oleh karena itu, dokter gigi muda dan perawat gigi muda yang tidak dapat mengendalikan atau mengontrol diri akan memiliki tingkat kecemasan yang tinggi.

Sebagai akhir pembahasan, peneliti mengidentifikasi beberapa keterbatasan penelitian.Pertama, skala yang diberikan saat pengambilan data pada beberapa subjek dokter gigi muda tidak dilakukan secara langsung oleh peneliti melainkan menitipkannya pada salah satu mahasiswa koas. Hal ini dikarenakan peneliti harus melakukan penelitian pada perawat gigi muda pada hari dan jam yang sama. Meskipun mahasiswa koas sudah mendapatkan penjelasan terlebih dahulu tentang karakteristik sampel yang akan dilibatkan dalam penelitian, namun ketika penelitian dilakukan, mahasiswa koas memberikan skala kepada subjek yang tidak sesuai dengan kriteria sampel penelitian, sehingga skala tersebut tidak dapat diskoring. Keadaan ini menyebabkan peneliti harus mencari sampel yang lain. Kedua, ketidaktelitian asisten peneliti dalam memeriksa kembali skala yang telah terisi, menyebabkan skala tidak dapat diskoring. Pada proses pengambilan data, banyak responden yang bertanya maksud dari pernyataan atau arti dari beberapa kata, sehingga peneliti harus menerangkan kembali maksud dari pernyataan atau kata tersebut

\section{SIMPULAN}

Hasil penelitian ini menunjukkan bahwa ada perbedaan tingkat kecemasan yang signifikan antara dokter gigi muda dan perawat gigi muda saat menghadapi pasien. Hal ini dikarenakan oleh beberapa faktor yaitu, tuntutan lingkungan belajar yang dialami oleh dokter gigi muda lebih tinggi dan penuh dengan tekanan (stresful) seperti, kurikulum materi yang menuntut dokter gigi muda untuk memiliki bermacammacam kemampuan dan keahlian, termasuk kemahiran dalam pengetahuan teori, kompetensi klinik, dan keterampilan dalam berhubungan dengan orang-orang (interpersonal skill), sedangkan tingkat kecemasan yang dialami oleh perawat gigi lebih rendah dibandingkan dokter gigi muda hal ini disebabkan oleh beban kerja yang dilakukan oleh perawat gigi lebih bersifat fisik seperti melakukan perawatan ringan (seperti penambalan pada gigi, pencabutan gigi dan pembersihan karang gigi), merapikan kursi dental unit, mensterilkan alat-alat gigi.

\section{SARAN}

Saran bagi peneliti selanjutnya yaitu diharapkan ada penelitian lanjutan tentang kecemasan trait yaitu kecemasan yang bersifat menetap pada diri individu dan berhubungan dengan kepribadiannya, karena dalam penelitian ini peneliti hanya melihat kecemasan state, yaitu kecemasan yang timbul ketika individu dihadapkan pada situasi situasi tertentu dan menetap selama situasi itu masih ada, sehingga bagi peneliti selanjutnya yang ingin meneliti tentang kecemasan diharapkan agar lebih menspesifikkan subjek penelitian berdasarkan jenis kecemasan, kemudian juga disarankan untuk peneliti selanjutnya agar melihat pengaruh variabel-variabel lain terhadap tingkat kecemasan seperti dukungan sosial, dan kepercayaan diri. Saat melakukan penelitian, diharapkan peneliti dapat mendampingi subjek dalam mengisi skala penelitian, karena meskipun sudah diuji coba ada juga beberapa subjek yang tidak memahami pernyataan yang 
terdapat dalam skala, kemudian disarankan untuk penelitian selanjutnya agar menggunakan metode penelitian kualitatif sebagai tambahan data untuk memperkuat data kuantitatif yang sudah ada.

\section{DAFTAR PUSTAKA}

Alzahem, A. M; Vander, M. H. T; Alaijan. A. H ; Achmidt.H. G ; Zamakhshary. M. H. (2011). Stres, Anxiety Among Dental Students: A Systematic Review. European Journal of Dental Education. 15: 8-18.

Dennis, G. \& Christine, A (2004).Manajemen

Pikiran.Bandung : PT. Mizan Pustaka.

Nursalam.(2002).

Manajemen

Keperawatan (Aplikasi dalam

Praktik

Keperawatan

Profesional). Jakarta: Salemba Medika.

Suliswati, (2005).Konsep dasar keperawatan kesehatan jiwa. Jakarta: EGC.

\section{Sumber Internet}

Dapartemen Kesehatan Republik Indonesia.(2008). Standar Profesi Perawat Gigi. Diunggah tanggal 26 Januari 2013, dari http://perpustakaan.depkes.go.id: 8180/bitstream//12 3456789/772/4/BK2008G137.pdf

Hartoyo, B. (2008). Hubungan Tingkat Pengetahuan dengan Tingkat Kecemasan Perawat dalam Melakukan Asuhan Keperawatan Pada Pasien Flu Burung di Ruang EID dan ICU RSUP Dr. Kariadi Semarang.Skripsi.Semarang : Universitas Diponegoro.

Karaogli. N \& Seker. M. (2006).Kecemasan dan Depresi pada Mahasiswa Kedokteran yang Berkaitan dengan
Keinginan dan Harapan dari Karier Kedokteran.Universitas Kristen Maranatha Bandung.Skripsi.Diunggah tanggal 1 juni 2013, dari http://www.scribd.com/doc/1261 16009/Kecemasan-Dan-DepresiPada-Mahasiswa-KedokteranYang-Berkaitan-DenganKeinginan-Dan-Harapan-DariKarier.

Konsil Kedokteran Indonesia (2006). Standar Profesi Pendidikan Dokter. Jakarta Selatan: Konsil Indonesia. Diunggah tanggal 26 Januari 2013, dari http://pormikijabar.com/wpconte nt/uploads/2011/12/MANUALREKAM-MEDIS.pdf

Lestarianita.P \& Fakhrurrozi. M. (2007) Pengetesan stres dan cemas pada perawat pria dan wanita .Jurnal Psikologi. Vol 1, No.1. Fakultas Psikologi Universitas Gunadarma.

Prasetyo, A \& Wurjaningrum, F. (2008).Pengaruh Stres terhadap komitmen Mahaiswa Universitas Airlangga Untuk Menyelesaikan Pendidikan dengan Faktor Kecemasan Sebagai Variabel Moderator.Skripsi. Universitas Airlangga.

Proborani, T.I ; Hartati, S ; Sawitri,D.R. (2010). Hubungan Antara Kemampuan Koping Terhadap Stres Dengan Kemampuan Empati Perawat Di RS. Telongorejo Semarang. Skripsi.(Serial Online).Diunggah tanggal 15 Oktober 2012, dari http://eprints.undip.ac.id/8582/1/ Koping_dan_Empati.pdf.

Polimpung, J.A .F. (2012). Pengaruh Stres, Depresi, dan Kecemasan terhadap Volume Saliva Pada Mahasiswa Preklinik Fakultas Kedokteran Gigi Universitas 
Hasanuddin. Skripsi. Diunggah tanggal 22 Mei 2013, dari http://www.google.com/search?/c omplete/se

arch? client $=\operatorname{serp} \& h l=e n \& g s_{-} \_n$

$=14 \& g s \_r i=\operatorname{serp} \& p q=a d a \% 20 p$

Puspitasari, Y. P ; Abidin, Z ; Sawitri, D.

R. (2010). Hubungan Antara

Dukungan Sosial Teman Sebaya

Dengan Kecemasan Menjelang

Ujian Nasional (UN) Pada Siswa

Kelas XII Reguler SMA Negeri 1

Surakarta.Jurnal psikologi.

Universitas Diponegoro.

Diunggah tanggal 28 november

2012,

dari

http://eprints.Undip.ac.id/24776/

1/Dukungan_sosial_

teman_sebaya_dan_kecemasan_ UAN.pdf.

Sijangga, W. N. (2010). Hubungan antara strategi coping dengan kecemasan menghadapi persalinan pada ibu hamil hipertensi.Skripsi.Universitas Muhammadiyah Surakarta.

Suyamto ; Prabandari, Y. S ; Marchira, C. R (2009). Pengaruh Relaksasi Otot Dalam Menurunkan Skor Kecemasan T-Tmas Mahasiswa Menjelang Ujian Akhir Program engaruh\%20stres\%20terhadap\% 20 volume $\% 20$ saliva\%20pada\%2 Omahasiswa\%20preklinik\%20fak ultas\%20kedokteran\%20gigi\%20 Universitas\%20Hasanuddin.

Di Akademi Keperawatan Notokusumo Yogyakarta. Diunggah tanggal 28 November 2012, dari http://isjd.pdii.lipi.go.id/admin/ju rnal/25309142149.pdf.

Widosari, M. (2010). Perbedaan Derajat Kecemasan Dan Depresi Mahasiswa Kedokteran Preklinik Dan Ko-asisten Di FK UNS Surakarta. Skripsi. (serial Online). Di unggah tanggal 26 September 2012, dari http://eprints.uns.ac.id/81/1/1684 10609201010551.pdf.

Wiyono, W \& Widodo, A. (2010).Hubungan Antara Tingkat Kecemasan Dengan Kecendurungan Insomnia pada Lansia Di Panti Wredha Dharma Bhakti Surakarta.Jurnal Berita Ilmu Keperawatan. 2 (2): 87-92. 